\title{
Comunicación
}

\section{SEROPREVALENCIA DEL VIRUS DE LA DIARREA VIRAL EN BOVINOS DE CRIANZA EXTENSIVA DE LA PROVINCIA DE SAN PABLO, CAJAMARCA}

\author{
Seroprevalence of Bovine Viral Diarrhea Virus in Grazing Cattle in \\ Cajamarca, Peru
}

\section{Antonio Herrera R. ${ }^{1}$, Alberto Manchego S. ${ }^{1,2}$, Mercy Ramírez V. ${ }^{1}$, Juan More B. ${ }^{1}$, Hermelinda Rivera G. ${ }^{1}$}

\section{RESUMEN}

El objetivo del presente estudio fue determinar la seroprevalencia del virus de la Diarrea Viral Bovina (VDVB) en bovinos criollos de crianza extensiva, sin historia de vacunación, en la provincia de San Pablo, Cajamarca. Se emplearon 385 muestras del banco de sueros, colectadas en el 2004. Las muestras se estratificaron en cuatro grupos etarios ( 2 a $<6,6$ a $<12,12$ a $<24$ y $>24$ meses) y por sexo. La detección de anticuerpos contra el VDVB se hizo mediante la prueba de neutralización viral. El 27.1 $\pm 4.4 \%(104 / 385)$ de los bovinos presentó anticuerpos contra el VDVB indistintamente del grupo etario o sexo; sin embargo, el $71.2 \pm 8.7 \%$ (47/66) de los animales entre 12 y 24 meses de edad presentaron títulos de anticuerpos entre 128 a $>256$. Se concluye que el VDVB está presente con una prevalencia baja en la población de bovinos de la provincia de San Pablo.

Palabras clave: virus de la Diarrea Viral Bovina, bovinos criollos, seroprevalencia, neutralización viral

\section{Abstract}

The aim of this study was to determine the seroprevalence of Bovine Viral Diarrhea virus (BVDV) in grazing cattle without history of vaccination, in the province of San Pablo, Cajamarca, Peru. It was used 385 samples from the serum bank, collected in 2004. Samples were stratified in four age groups ( 2 to $<6,6$ to $<12,12$ to $<24$, and $>24$ months) and by sex. The detection of antibodies against BVDV was done by the viral neutralization test. The $27.0 \pm 4.4 \%(104 / 385)$ of samples had antibodies against BVDV, and without statistical difference due to age or sex; however, $71.2 \pm 8.7 \%(47 / 66)$ of animals between

${ }^{1}$ Laboratorio de Microbiología y Parasitología Veterinaria, Facultad de Medicina Veterinaria, Universidad Nacional Mayor de San Marcos, Lima

${ }^{2}$ E-mail: amanchegos@unmsm.edu.pe 
12 and 24 months of age showed antibody titres between 128 and $>256$. It was concluded that the BVDV is present with a low seroprevalence in the cattle population of San Pablo province, Cajamarca.

Key words: Bovine Viral Diarrhea virus, criollo cattle, seroprevalence, viral neutralization

La población bovina en el Perú está conformada mayormente por ganado criollo, con 3.8 millones de cabezas, aproximadamente. El $86 \%$ de esta población es criado en los valles interandinos, principalmente en forma extensiva, compartiendo las áreas de pastura con otros rumiantes domésticos, y pertenecen a pequeños y medianos ganaderos con escasa organización y pobre tecnología de crianza (INEI, 1995). Según el III Censo Nacional Agropecuario, el departamento de Cajamarca cuenta con cerca de 600000 cabezas de ganado bovino y la provincia de San Pablo con más de 16000 bovinos (INEI, 1995).

En el 2003, el Proyecto de Desarrollo Ganadero (PRODEGAN) de la provincia de San Pablo, a través de un diagnóstico situacional de la actividad pecuaria, determinó que existían 12620 bovinos en San Pablo, principalmente de tipo criollo, Holstein y Brown Swiss, atribuyendo la disminución de la población a factores tales como inadecuado manejo de los animales que los predispone a problemas sanitarios, entre los que podría estar relacionado el virus de la Diarrea Viral Bovina (VDVB).

La Diarrea Viral Bovina (DVB) es una de las enfermedades de mayor distribución en la población bovina del país (Rivera, 2008); principalmente, en las cuencas lecheras donde alcanza prevalencias mayores al 50\%, disminuyendo la capacidad reproductiva y formando parte del complejo respiratorio en bovinos (Rivera, 1993). La prevalencia de la DVB depende del tipo de ganado, densidad poblacional, tipo de manejo, comercio de animales, y manejo de las pasturas, entre otros factores (Houe 1995, 1999; Rivera, 2008).
La industria lechera en el Perú se concentra básicamente en las cuencas de Arequipa, Lima y Cajamarca (MINAG, 1996), y en la actualidad existe un interés creciente en el desarrollo ganadero en los valles interandinos con disponibilidad forrajera. Sin embargo, en muchas de estas zonas, como es el caso de la ganadería de la provincia de San Pablo, no se cuenta con informaciones sanitarias respecto a enfermedades que limitan el desarrollo ganadero. El objetivo del presente estudio fue determinar la seroprevalencia del VDVB en animales criollos de esta provincia cajamarquina para contribuir al mejor conocimiento de la epidemiología de la enfermedad en el país.

Se trabajó con 385 muestras de suero que forman parte del banco de sueros del Laboratorio de Virología de la Facultad de Medicina Veterinaria, Universidad Nacional Mayor de San Marcos, Lima. Las muestras se obtuvieron a través de un trabajo colaborativo con el Programa de Desarrollo Ganadero (PRODEGAN, 2003) en la provincia de San Pablo, departamento de Cajamarca, en el 2004.

Los sueros estuvieron almacenados en congelación a $-20^{\circ} \mathrm{C}$. Se evaluó la presencia de anticuerpos contra el VDVB mediante la prueba de neutralización viral. Para esta prueba se utilizó cultivos secundarios de células de cornete nasal de feto bovino normal, que estaban libres de VDVB según la prueba de inmunofluorescencia directa. En la prueba de neutralización viral se utilizó la cepa viral Singer, prototipo del biotipo citopático del VDVB genotipo 1. Una muestra fue considerada positiva cuando el efecto citopático estuvo ausente en una dilución igual o mayor a 1:2. Asimismo, el título de anticuerpos fue 
Cuadro 1. Distribución de los títulos de anticuerpos contra el virus de la Diarrea Viral Bovina en bovinos de la provincia de San Pablo, Cajamarca, detectados mediante la prueba de neutralización viral

\begin{tabular}{lccccccc}
\hline & & \multicolumn{5}{c}{ Inversa de títulos de anticuerpos } \\
\cline { 3 - 8 } $\begin{array}{l}\text { Edad } \\
\text { (meses) }\end{array}$ & $\begin{array}{c}\text { Animales } \\
\text { positivos }\end{array}$ & \multicolumn{2}{c}{2 a 8} & \multicolumn{2}{c}{16 a 64} & \multicolumn{2}{c}{$128 \mathrm{a}>256$} \\
\cline { 3 - 9 } & & $\mathrm{N}^{\circ}$. & $\%$ & $\mathrm{~N}^{\circ}$. & $\%$ & $\mathrm{~N}^{\circ}$. & $\%$ \\
\hline $2 \mathrm{a}<6$ & 7 & 0 & $0 \pm 6.4$ & 4 & $57.1 \pm 9.5$ & 3 & $42.9 \pm 9.5$ \\
$\geq 6$ a $<12$ & 14 & 5 & $35.7 \pm 9.2$ & 3 & $21.4 \pm 7.9$ & 6 & $42.9 \pm 9.5$ \\
$\geq 12$ a $<24$ & 66 & 5 & $7.5 \pm 5.1$ & 14 & $21.2 \pm 7.9$ & 47 & $71.2 \pm 8.7$ \\
$\geq 24$ & 17 & 3 & $17.6 \pm 7.3$ & 11 & $64.8 \pm 9.2$ & 3 & $17.6 \pm 7.3$ \\
\hline Total & 104 & 13 & $12.5 \pm 6.4$ & 32 & $30.8 \pm 8.9$ & 59 & $56.7 \pm 9.5$ \\
\hline
\end{tabular}

la dilución más alta capaz de neutralizar las $100 \mathrm{DI} \mathrm{F}_{0} \mathrm{CC} / 50$ ? 1 del virus.

Las muestras se estratificaron en base al sexo del animal $($ machos $=100$; hembras $=$ 285) y grupos etarios ( 2 a menos de 6 meses $=32$; entre 6 a menos de 12 meses $=67 ; 12$ meses o mayores $=286$ ). La asociación entre la seropositividad al VDVB, el sexo y los grupos etarios se determinó mediante las pruebas del Chi Cuadrado y Regresión Logística, utilizando el programa estadístico STATA $10 \AA$, con un nivel de significación de 0.05 .

El $27.1 \pm 4.4 \%(104 / 385)$ de las muestras presentaron anticuerpos contra el VDVB, sin encontrar diferencia estadística por efecto de la edad o sexo. El $71.2 \pm 8.7 \%$ (47/66) de animales entre 12 y 24 meses de edad tuvieron títulos entre 128 y mayores a 256 (Cuadro 1$)$. El sexo $(\mathrm{OR}=0.97)$ y el grupo etario ( $\geq 6$ a $<12:$ OR $=0.94 ;>12$ meses: $\mathrm{OR}=1.45$ ) no representaron factores de riesgo para la seropositividad contra el VDVB.

La seroprevalencia encontrada fue relativamente baja en comparación a estudios realizados en otras zonas del país (Contreras et al., 2000; Rivera et al., 2001, 2003; Cabello et al., 2006; Zúñiga et al., 2006; Huamán et al., 2007; Rivera, 2008). La vacunación contra la DVB, como medida preventiva, no figura dentro del programa sanitario que utilizan los ganaderos de San Pablo, de allí que los anticuerpos detectados no fueron de origen vacunal, sino inducidos por el virus de campo. La prevalencia no estuvo afectada por sexo o grupo etario, sugiriendo que la población bovina fue desafiada por el virus poco tiempo antes del muestreo; sin embargo, también podría explicarse por el tipo de crianza extensiva, donde la infección no se difunde tan rápidamente como ocurre en una crianza intensiva (Houe, 1995).

No se dispone de información respecto a cómo y cuándo ingresó el virus a la zona; pero como ha ocurrido en otros lugares del país, el virus, posiblemente, ingresó con la introducción de animales genéticamente mejorados, procedentes de áreas como la campiña de Cajamarca donde la DVB está difundida, o a través de animales adquiridos en ferias de la región (H. Rivera, Lima, comunicación personal). Usualmente, más del $70 \%$ de los animales inmunocompetentes infectados por el VDVB presentan una infección subclínica, pero eliminan al virus a través de sus secreciones por un corto periodo (Houe, 1995); sin embargo, los principales reservorios y diseminadores del virus son los animales portadores o persistentemente in- 
fectados (PI), por lo que la alta prevalencia del VDVB en una zona o hato está asociado a la presencia de animales PI (Houe, 2003).

La mayor prevalencia, aunque no significativa, se detectó en bovinos mayores a 12 meses, indicando una relación directa entre la edad y la seropositividad, compatible con otros reportes (Ferrari et al., 1999). La mayor prevalencia del VDVB observado en animales de más edad es debido a que el VDVB induce altos niveles de anticuerpos que persisten por largo tiempo (Brownlie, 1991; Fredriksen et al., 1999).

Los títulos de anticuerpos concuerdan con los resultados de Mainar-Jaime et al. (2001), quienes encuentran una estrecha relación entre edad y seropositividad a anticuerpos. Sin embargo, se tuvo tres terneros con títulos altos de anticuerpos, y estos podrían corresponder a anticuerpos pasivos o a infecciones de reciente introducción al rebaño.

En el Perú la infección por el VDVB es principalmente de tipo subclínico, posiblemente debido a la benignidad del clima o la menor densidad de la población bovina (Contreras et al., 2000). Los resultados del presente estudio evidencian que el VDVB está moderadamente difundido en el ganado bovino de crianza extensiva en la provincia de San Pablo, Cajamarca.

\section{Agradecimiento}

Los autores desean expresar su agradecimiento al Dr. César Gavidia Chucán por su apoyo en el análisis estadístico.

\section{Limeratura Citada}

1. Brownlie J. 1991. The pathways for bovine virus diarrhoea virus biotypes in the pathogenesis of disease. Arch Virol [Supl 3]: 79-96.

2. Cabello K, Quispe R, Rivera H. 2006. Frecuencia de los virus parainfluenza-3, respiratorio sincitial y diarrea viral bovina en un rebaño mixto de una comunidad campesina de Cusco. Rev Inv Vet, Perú 17: 167-172.

3. Contreras G, Ståhl K, Arana C, Rivera H. 2000. Anticuerpos contra el virus de la diarrea viral bovina en muestras de leche de bovinos del valle del Mantaro (Jauja, Concepción y Huancayo). Rev Inv Vet, Perú 11(1): 58-65.

4. Ferrari $G$, Scicluna MT, Bonvicini $D$, Gobbi C, Della Verità F, Valentini A, Autorino GL. 1999. Bovine virus diarrhoea (BVD) control programme in an area in the Rome province (Italy). Vet Microbiol 64: 237-245.

5. Fredriksen B, Sandvik T, Løken T, $\emptyset$ degaard SA. 1999. Level and duration of serum antibodies in cattle infected experimentally and naturally with bovine virus diarrhoea virus. Vet Rec 30: 111-114.

6. Houe H. 1995. Epidemiology of Bovine Viral Diarrhea virus. Vet Clin NA-Food A 11: 521-547.

7. Ноие H. 1999. Epidemiological features and economical importance of bovine virus diarrhoea virus (BVDV) infections. Vet Microbiol 64: 89-107.

8. Houe H. 2003. Economic impact of BVDV infection in dairies. Biologicals 31: 137-143.

9. Huamán JC, Rivera H, Araínga M, Gavidia C, Manchego A. 2007. Diarrea viral bovina y animales portadores del virus en hatos productores de leche de la irrigación de Majes, Arequipa. Rev Inv Vet, Perú 18: 141-149.

10. [INEI] Instituto Nacional de Estadística e Informática. 1995. III Censo Nacional Agropecuario. Lima, Perú. Resultados Definitivos: Departamento de Cajamarca. Disponible en: www.inei.gob.pe/

11. Mainar-Jaime RC, Berzal-Herranz B, Arias P, Rojo-Vázquez FA. 2001. Epidemiological pattern and risk factors associated with bovine viral-diarrhoea virus (BVDV) infection in a nonvaccinated dairy-cattle population from the Asturias region of Spain. Prev Vet Med 52: 63-73. 
12. [MINAG] Ministerio de Agricultura del Perú. 1996. Producción pecuaria e industria avícola. Presidencia de la República. Documento de consulta. Lima: MINAG. 100 p.

13. [PRODEGAN] Programa de Desarrollo Ganadero. 2003. Diagnóstico situacional de la actividad pecuaria de la provincia de San Pablo. Municipalidad de San Pablo, Cajamarca. Bol N ${ }^{\circ}$ 2: 5-11.

14. Rivera H, Huamán K, Benito A, Díaz $A$, Arana C. 2003. Prevalencia del virus de la diarrea viral bovina y animales portadores del virus en un hato lechero del valle del Mantaro. Rev Acad Peru Cienc Vet 3: 1-7.
15. Rivera H, Valdivia L, Benito A. 2001. Diarrea viral bovina en bovinos lecheros de crianza semi-intensiva de la provincia de Parinacochas, Ayacucho. Rev Inv Vet, Perú [Supl 1]: 380-381.

16. Rivera H. 1993. El virus de la diarrea viral bovina (DVB). Rev Inv Pec IVITA 6(1): 1-6.

17. Rivera H. 2008. Evolución del conocimiento sobre la enfermedad de la diarrea viral bovina y su agente etiológico. Rev Inv Vet, Perú 19: 93-112.

18. Zúñiga A, Rivera H, Araínga M, Manchego A. 2006. Evaluación de anticuerpos contra el virus de la diarrea viral bovina de un hato en proceso de erradicación de la enfermedad. Rev Inv Vet, Perú 17: 44-50. 